ISMC 2021

$16^{\text {th }}$ International Strategic Management Conference

\title{
PERCEIVED GENDER DISCRIMINATION AND TURNOVER INTENTION: THE MEDIATING ROLE OF CAREER SATISFACTION
}

\author{
Meral Elçi (a), Arzu Sert-Özen (b), Gülay Murat-Eminoğlu (c)* \\ *Corresponding author \\ (a) Gebze Technical University, 41400, Kocaeli, Turkey, emeral@gtu.edu.tr \\ (b) Free Researcher, Kadıköy, Istanbul, arzusertt@gmail.com \\ (c) Gebze Technical University, 41400, Kocaeli, Turkey, gulaymurat@gtu.edu.tr
}

\begin{abstract}
Gender-based discrimination is a world-wide -inequality, diversity, and exclusion- issue. Gender discrimination toward women is a never-ending story in every aspect of the workplace. Thus, this crosssectional study is planned to glance at gender-based discrimination perceptions of Turkish female employees to evaluate its work-related consequences. Previous studies have found that female employees often experience gender-based discrimination related to important organizational outcomes. This crosssectional study examines the relationship between perceived gender discrimination and turnover intention and tests whether career satisfaction has a mediating role in the relationship between perceived gender discrimination and turnover intention. The research sample consists of 256 white collar female employees working in different industrial areas including finance, chemical, health, education, transportation, logistics and communication in Turkey. As predicted, the research findings indicated that perceived gender discrimination and turnover intention is positively related and career satisfaction has partial mediating role in this relationship. Based on the results, directions for future research were presented and in addition, the practical implications were discussed.
\end{abstract}

2357-1330 (c) 2021 Published by European Publisher.

Keywords: Career satisfaction, female employees, perceived gender discrimination, turnover intention 


\section{Introduction}

Increasing the number of highly skilled and talented women in the labour force offers social opportunity and challenge for both female employees and the organizations. Though a good number of positive organizational outcomes of female employees' employment, perceived gender discrimination is still a worldwide unsolved issue because of discriminatory organizational practices and keep influencing female employees' career advancement, subjective well-being, job/career satisfaction and performance (Joo \& Park, 2010; Kim, 2015).

Women are trying to make their business life sustainable in the male-dominated business world. Accordingly, they may need to perform as twice as men in the same position. Although high performance leads women to success, their efforts to become perfect against men, can sometimes make women unsuccessful on the contrary. Women, who are constantly in the feeling of weaknesses and deficiency because of gender-based discrimination, may not only intent to leave their career goals, but also their jobs in the present organization (Yücelen \& Özen, 2010). In organizations where gender discrimination is perceived, undesirable consequences such as reduced performance and employee engagement, increased turnover of talented employees, and numerous immeasurable harmful effects can occur (Shaffer et al., 2000). Relative deprivation theory (Crosby, 1976), which refers to negative feelings caused by job-related outcomes which is unequal or worse compared to a referent group or a standard, suggest that dissatisfaction occurs in the presence of such discrepancy. This process consists of the employee's subjective judgements, rather than objective circumstances (Ren et al., 2013). Therefore, as Kim (2015) noted, perceived gender discrimination is more important in predicting satisfaction than actual gender discrimination. Faced with systemic inequality, female faculty members perceive it as a career barrier in their work life (Bird \& Rhoton, 2021). Gender-based barriers for highly qualified and talented female workforce especially in the disciplines such as science, mathematics, engineering, technology, are an important problem that must be overcome for the success of both science and organizations (Bird \& Rhoton, 2021; Chan et al., 2016; Salleh et al., 2020).

Kern et al. (2020) suggested that although the link between gender-based discrimination and career satisfaction was demonstrated in their study, more research is needed. In addition, research suggested that intention to leave is not just a will searching for a new job, low level of career satisfaction is one of the most important reasons behind intention to leave and the possible links should be investigated (Kang et al., 2015; Salleh et al., 2020). Many studies (e.g., Kern et al., 2020; Qu et al., 2020; Zopiatis et al., 2018) pointed out the significant relationships between gender discrimination, career satisfaction and turnover intention separately, however any research linking these three variables has not been conducted.

The present study aims at contributing to the gender discrimination literature in two ways. First, it offers an understanding on the outcomes of being subjected to gender discrimination in the workplace as a sample of female employees in Turkey, and second, career satisfaction is investigated as a mediator between gender discrimination and turnover intention for the first time. 


\section{Literature Review and Theoretical Framework}

\subsection{Gender Discrimination}

Gender discrimination in the workplace is defined as gender-based unfair treatment in human resources practices such as recruitment and selection, performance appraisal and compensation. Employees belonging to a certain gender group often perceive gender discrimination when they are limited or excluded from decision making process, or other activities in the workplace and inhibited in their career advancement in comparison to another gender group ( $\mathrm{Qu}$ et al., 2020). Even though experiencing gender-based discrimination is possible among male employees in the workplace, gender discrimination against female employees is more widespread problem especially in male-dominated cultures such as Turkey, China, Korea, and Japan (Balkan \& Cilasun, 2018; Kim et al., 2015; Qu et al., 2020). In European settings, gender-based discrimination may be experienced as well. In a study by Traavik (2018), many Norwegian women surprisingly and sadly reported that they perceived gender discrimination at high level. In addition, women face discrimination in traditionally male-dominated career paths and disciplines including technology, science, and engineering. Women who become successful at crossing the hiring barrier in the male-dominated work environment, face problem in gaining professional trust and respect from their male counterparts (Lourens, 2014).

Why does gender discrimination matter? A good number of research have demonstrated that perceived gender discrimination is related to important work outcomes such as work engagement (Kim, 2015), job satisfaction (Andersson \& Harnois, 2020; Janjua et al., 2020; Kim, 2015; Shaffer et al., 2000), career satisfaction (Kern et al., 2020), organizational identification (Qu et al., 2020), affective commitment (Qu et al., 2020; Shaffer et al., 2000), turnover intention (Qu et al., 2020; Shaffer et al., 2000), occupational stress (Dilrukshi \& Ranasinghe, 2021), subjective career success (Park et al., 2017), job performance (Dilrukshi \& Ranasinghe, 2021), and psychological symptoms such as mental health, sleep problems, and unhappiness (Andersson \& Harnois, 2020).

\subsection{Career Satisfaction}

Seibert and Kraimer (2001) described career satisfaction as a person's emotional state deriving from by an individual's positive evaluation of one's career or career related experiences. Career satisfaction is basically considered a self-reported measure of individuals' subjective assessments of how successful they have been or believe they have been in their careers.

As Pelenk (2020) noted in his study, it is stated in the Social Exchange Theory (Homans, 1961) that every effort has a reward, and that the employee wants to be rewarded for their efforts. Career success is one of the positive results that the employee receives in return for his/her effort. Career satisfaction has two dimensions, objective and subjective. Subjective career satisfaction includes the employee's evaluation of success. Objective career satisfaction consists of general indicators such as promotion, wage, and premium increase (Gerçek et al., 2015). Ding and Lin (2006) stated that organizations that improve their employees' career satisfaction are closer to achieving organizational goals. The research of Martínez-León, et al. (2018) demonstrated that low career satisfaction reduces the employees' performance. Greenhaus et al. (1990) argued that increasing employee career satisfaction 
decreases the negative impact of job-related stress, in turn, lower level of job-related stress improves employees' performance. Lv and Yu (2020) found that employee career satisfaction is positively related to organizational citizenship behaviour. However, there are also factors that negatively affect career satisfaction. These elements are workload, unequal rewards, conflict, discrimination, and stress (Lepnurm et al., 2006).

\subsection{Turnover Intention}

Turnover intention is defined as the desire to leave an organization by choice (Tett \& Meyer, 1993). It is one of the most important predictors of actual turnover rate (Griffeth et al., 2000), therefore, traditionally scholars have investigated turnover intention rather than actual turnover rate to understand the process ended up with actual leaving the job or organization (Cohen et al., 2016). Turnover intention has three cognitive processes including initial thoughts of leaving the organization, intention to seek a new job and intention to leave the present organization (Chan \& Mai, 2015).

There are many vital predictors of turnover intention. Job satisfaction has been examined in a good number of studies and has been generally recognized as a key factor in turnover (Lee et al., 2010; Özkan et al., 2020). In addition, leadership-related factors, such as ethical leadership, leadership effectiveness and work-related stress (Elçi et al., 2012), supervisor support, organizational commitment, self-esteem were frequently identified as important predictors of turnover intention (Siong et al., 2006).

\subsection{Gender Discrimination and Career Satisfaction}

Regardless of who perceived gender discrimination had lower career satisfaction (Kern et al., 2020). However, there are some empirical studies that have demonstrated that women are more likely than men to experience gander-based discrimination on their career advancement and its negative impacts in career satisfaction. Career satisfaction is a feeling deriving from perceived acceptance. The feeling of being isolated or underestimated by male counterparts, being inhibited having entire resources and information needed for tasks to be performed has a negative impact on career satisfaction of female employees (Chovwen, 2007).

Gender often determines women's boundaries and choices as consequence of social arrangements. In many contemporary organizations, there is a gendered hierarchical culture shaped by gender that privileges men and excludes women. This hierarchy is achieved by creating inequalities by re-interpreting women and men according to 'advantage' and 'disadvantage' computations based on gender (Bhatt, 2013). In a study by Bhatt (2013) female medical doctors who perceive patriarchal and sexist attitudes in their workplaces reported that they work harder to gain the respect of their supervisors and colleagues and are still directed to less prestigious career fields. These highly qualified professional females who are overwhelmed with psychological pressure, will have to either accept the barriers to their career progress or manifest every obstacle that they face but at any choice, there may be negative consequences for their mental health, life, and career satisfaction (Treanor et al., 2021).

A good number of studies suggested that gender discrimination is negatively related to career satisfaction (Carr et al., 2000; Chovwen, 2007; Ecklund et al., 2012; Kern et al., 2020; Park et al., 2017). Carr et al. (2000) found that women medical school faculty members were 2.5 times more likely to report 
gender discrimination than male faculty members in the academic environment and women who perceived gender discrimination had lower career satisfaction. In a research review by Chovwen (2007), male dominance at work reported as feeling of discrimination and has negative impact on career satisfaction. Ecklund et al. (2012) examined the gender discrimination among women and men academic scientists working in the disciplines of physics and biology. The findings suggested that career stages and gender-based differences in physics and biology are related. In particularly women scientists are more likely to report discrimination in comparison to men scientists. General results suggests that perceptions of gender-based discrimination in science are high. Similarly, Kern et al. (2020) examined relationships between gender-based discrimination and career satisfaction. The results indicated that women are more likely to experience work-related discrimination than men. In addition, the study identified the gender is the most common issue of perceived discrimination and this perception was higher among those who had lower career satisfaction. Park et al. (2017) investigated the relationships among leader-member exchange (LMX), perceived gender-based discrimination and career success. The results of the study indicated that gender discrimination factors including promotion, employment, wage, and training discrimination influenced career success. Similarly, we expected that if female employees perceive gender discrimination, their career satisfaction will be lower. The proposed hypothesis follows:

$\mathrm{H}_{1}$ : Gender discrimination is negatively related to career satisfaction.

\subsection{Career Satisfaction and Turnover Intention}

Scholars address career satisfaction as one of the major factors that determines turnover. When employees' psychological well-being and their career satisfaction are low, they are likely to leave the job. Higher level of career satisfaction positively impacts employees' commitment to their organization, and thus, not just encourages employees to stay, but also keeps the talented people in the organization (Joo \& Park, 2010; Zopiatis et al., 2018). According to Kezar and Acuña (2021), although both male and female academicians are committed to their academic careers equally, when female academics are dissatisfied with their career advancement and opportunities, they are more prone to leave.

There are considerable empirical studies that have demonstrated that career satisfaction negatively influences employees' turnover intention (Chan \& Mai, 2015; Chan et al., 2016; Joo \& Park, 2010; Salleh et al., 2020; Zopiatis et al., 2018). Joo and Park (2010) investigated the relationship between career satisfaction and turnover intention. The results indicated that career satisfaction is a significant predictor of turnover intention. Salleh et al. (2020) examined the mediating role of career satisfaction in the relationship between career planning and turnover intention. The findings indicated that career satisfaction is negatively related to turnover intention. In addition, the study identified that career satisfaction had a partially mediating role in the relationship between career planning and turnover intention. Chan and Mai (2015) found that when employees having a job at a lower level than others in the organization (low-ranking employees) have higher levels of satisfaction with their career well-being and achievement, they will not be searching for a new job. Chan et al. (2016) demonstrated that career satisfaction influences employees' turnover intention stronger than career adaptability. Zopiatis et al. (2018) investigated the effects of career satisfaction on intention to remain among employees working in the hospitality industry in Cyprus. The research results suggested that career satisfaction has a positive effect on employees' intention to remain within the hospitality industry. The general results of the studies 
suggest that lower level of career satisfaction would lead to higher level of employees' turnover intention. Based on this discussion, the proposed hypothesis as follows:

$\mathrm{H}_{2}$ : Career satisfaction is negatively related to turnover intention.

\subsection{Gender Discrimination and Turnover Intention}

According to gender stereotypes in the workplace, women are generally not allowed to be advanced in their careers. Stereotyping generally leads to the underestimating qualifications of women in the workplace or not allowing them to hold jobs that are thought to be inappropriate for their gender. Females who perceive the presence of stereotyping in the context of discrimination, choose to leave the organization, even they are committed to their careers (Kezar \& Acuña, 2021). In such a situation, women who prefer leaving their job avoiding from male domination environments, may even set up their own business to utilize their high-level expertise and full qualifications (Sheridan \& Newsome, 2021).

Gender discrimination has important negative outcomes for both the employee and the organization (Qu et al., 2020). Turnover intention is one of the important negative outcomes. Earlier studies demonstrated that perceived gender discrimination influence negatively employees' turnover intention (Foley, Hang-Yue, \& Wong, 2005; Foley, Ngo \& Loi, 2006; Qu et al., 2020; Shaffer et al., 2000).

Foley et al. (2005) investigated the relationship between gender discrimination and turnover intention among Protestant clergy in Hong Kong. In addition, the researchers examined the mediating effect of job satisfaction in the relationship between gender discrimination and turnover intention. The research results suggested that whereas perceived gender discrimination has direct effect on turnover intention, job satisfaction has no mediating effect in the relationship. Similarly, Foley et al. (2006) found that gender discrimination is significantly and positively related to turnover intention among practicing solicitors in Hong Kong.

Qu et al. (2020) investigated the relationship between Chinese hotel employees' perceived gender discrimination and organizational outcomes. The findings showed that perceived gender discrimination at work is positively related to employees' turnover intention. Similarly, Shaffer et al. (2000) found that gender discrimination has positive impact on turnover intention among 583 female employees in the US. Hong Kong and mainland China. Based on these theorical and empirical findings, the proposed hypothesis as follows:

$\mathrm{H}_{3}$ : Gender discrimination is positively related to turnover intention.

\subsection{The Mediating Effect of Career Satisfaction in the Relationship Between Gender Discrimination and Turnover Intention}

Female employees who perceive that her work environment is full of negative feelings toward women may lose their self-esteem. Because of their gender identity, they may think that striving to advance in their careers will not bring any benefit and making more effort will not work. Female employees who think that they are prevented from reaching higher positions in their careers and from having better opportunities because of their gender identity are more likely to leave the job and seek a new organization in which they are less marginalized, have an advantage in reaching a higher position, 
and have a certain maturity in advancing in their careers (Qu et al., 2020). Indeed, discrimination in the workplace shows that an organization does not treat everyone equal, so individuals who are discriminated, naturally feel themselves disadvantaged. In this vein, exposure to gender discrimination leads to a sense of being unsuccessful (Herrbach \& Mignonac, 2012).

Therefore, it is logical that female employees who feel that they are discriminated against because of their gender identities are more likely to experience a lower level of satisfaction in terms of their professional career, and in turn, lower level of career satisfaction increases the probability of being in search of a new job and leaving the organization.

$\mathrm{H}_{4}$ : Career satisfaction will mediate the relationship between gender discrimination and turnover intention.

\section{Research Method and Analysis}

\subsection{Sampling and Measures}

The current study consists of 256 female employees. Most women (82.5\%) are married and between the ages of 20-35. Of the total participants, $60.3 \%$ have a bachelor's degree and $25.7 \%$ have a master's or doctoral degree. $17.6 \%$ of the participants are in the education sector, $13 \%$ in the finance sector, $11.8 \%$ in the chemical sector, $10.6 \%$ in the health sector, and $3.9 \%$ in the transportation, logistics and communication sector and the remaining participants work in other sectors.

All the scales used in the current research were adapted from the earlier empirical studies. "Career Satisfaction" scale was adapted from Greenhaus et al. (1990). "Turnover Intention" was measured by the scale adopted from Mobley et al. (1979), and "Overt Gender Discrimination at Work" scale by Jagusztyn (2010) was used to measure the "Perceived Gender Discrimination".

\subsection{Measure Validity and Reliability}

Subsequently data collection, exploratory factor analysis was applied using principal components extraction with varimax rotation. The factors are divided into three variables as expected and all the items were distributed to the factors as it expected to be. All the factor loadings are above, 50. The KaiserMeyer-Olkin (KMO) index has been found as, 893 and is higher than the recommended ,50 value. Bartlett's test of sphericity is at statistically significant level of $0.00\left(x^{2}(136)=3840,713 ; p=.00\right)$.

Table 1 shows the means, standard deviations, and Cronbach's Alphas of the variables. The correlation coefficients are moderate as seen in Table 1. All Cronbach's Alphas are higher than 0.70 as suggested by Nunnaly (1978). These results demonstrate that the validity and reliability of our measurement is sufficient.

Table 1. Means, Std. Deviations, Cronbach's Alphas and Correlation Coefficients

\begin{tabular}{ccccccc}
\hline Variable & 1 & 2 & 3 & Means & $\begin{array}{c}\text { Std. } \\
\text { Deviations }\end{array}$ & $\begin{array}{c}\text { Cronbach } \\
\text { Alpha }\end{array}$ \\
\hline Gender Discrimination & 1 & & & 2,3885 & 1,36573 &, 955 \\
Turnover Intention &, $263^{* *}$ & 1 & & 3,0352 & 1,64312 &, 870 \\
Career Satisfaction &,$- 230^{* *}$ &,$- 333^{* *}$ & 1 & 4,6141 & 1,48576 &, 929 \\
\hline
\end{tabular}

**. Correlation is significant at the 0.01 level (2-tailed). 


\subsection{Hypothesis Testing}

We used regression analysis to test our hypotheses. According to the results (Table 2), Model-1 $\left(\mathrm{F}=14,134 ; \mathrm{R}^{2}=, 053 ; \mathrm{Sig}=, 000\right)$, Model-2 $\left(\mathrm{F}=31,733 ; \mathrm{R}^{2}=, 111 ; \mathrm{Sig}=, 000\right)$, and Model-3 $(\mathrm{F}=18,866$; $\left.\mathrm{R}^{2}=, 069 ; \mathrm{Sig}=, 000\right)$ are significant. In Model-1, it is found that gender discrimination is negatively related to career satisfaction $(\beta=-, 230$; $\operatorname{Sig}<0.01)$. As seen in Model-2, it is found that career satisfaction is negatively related to turnover intention $(\beta=-, 333$; $\mathrm{Sig}=, 000)$. And finally, in Model-3 it is found that gender discrimination is positively related to turnover intention $(\beta=, 263$; $\operatorname{Sig}=, 000)$. So, $\mathbf{H}_{1}, \mathbf{H}_{2}$ and $\mathbf{H}_{3}$ are supported according to the results.

Table 2. Regression Analysis Results

\begin{tabular}{|c|c|c|c|c|c|c|c|c|c|c|c|}
\hline & \multicolumn{3}{|c|}{$\begin{array}{c}\text { Model-1 } \\
\text { (DV: Career } \\
\text { Satisfaction) }\end{array}$} & \multicolumn{4}{|c|}{$\begin{array}{c}\text { Model-2 } \\
\text { (DV: Turnover } \\
\text { Intention) }\end{array}$} & \multicolumn{4}{|c|}{$\begin{array}{c}\text { Model-3 } \\
\text { (DV: Turnover } \\
\text { Intention) }\end{array}$} \\
\hline \multirow{5}{*}{ GD } & $\beta$ & $\mathrm{t}$ & Sig. & \multirow{2}{*}{ CS } & $\beta$ & $\mathrm{t}$ & Sig. & \multirow{2}{*}{ GD } & $\beta$ & $\mathrm{t}$ & Sig. \\
\hline &,- 230 & $-3,760$ &, 000 & &,- 333 & $-5,633$ &, 000 & & ,263 & 4,344 &, 000 \\
\hline & \multicolumn{3}{|c|}{$\mathrm{F}=14,134$} & \multicolumn{4}{|c|}{$\mathrm{F}=31,733$} & \multicolumn{4}{|c|}{$\mathrm{F}=18,866$} \\
\hline & \multicolumn{3}{|c|}{$\mathrm{R}^{2}=, 053$} & \multicolumn{4}{|c|}{$\mathrm{R}^{2}=, 111$} & \multicolumn{4}{|c|}{$\mathrm{R}^{2}=, 069$} \\
\hline & \multicolumn{3}{|c|}{$\operatorname{Sig}=, 000$} & \multicolumn{4}{|c|}{$\mathrm{Sig}=, 000$} & \multicolumn{4}{|c|}{ Sig $=, 000$} \\
\hline
\end{tabular}

Note 1: GD: Gender discrimination, CS: Career satisfaction

The mediator analysis was performed with PROCESS Macro on model 4 (Hayes, 2013). 5\% biascorrected confidence interval with 5,000 bootstrapping method was utilized. In Model-1, it is found that gender discrimination is positively related to turnover intention $(\beta=, 3164 ; \mathrm{p}<.01)$. Moreover, it is found that gender discrimination is negatively related to career satisfaction $(\beta=-, 2498 ; \mathrm{p}<0.01)$ showed in Model-2. In Model-3, both gender discrimination $(\beta=, 2368 ; \mathrm{p}<0.01)$ and career satisfaction $(\beta=-, 3186$; $\mathrm{p}<0.01)$ is related to turnover intention. When career satisfaction is included in the analysis, gender discrimination is still related to turnover intention, but the regression coefficient reduces from $(\beta=, 3164$; $\mathrm{p}<.01)$ to $(\beta=, 2368 ; \mathrm{p}<0.01)$. So, these models indicated that career satisfaction partially mediates the relationship between gender discrimination and turnover intention according to Baron and Kenny (1986) procedure.

Table 3. Mediation Analysis Result

\begin{tabular}{|c|c|c|c|c|c|c|}
\hline & \multicolumn{2}{|c|}{$\begin{array}{c}\text { Model-1 } \\
\text { (DV: Turnover } \\
\text { Intention) } \\
\end{array}$} & \multicolumn{2}{|c|}{$\begin{array}{c}\text { Model-2 } \\
\text { (DV: Career } \\
\text { Satisfaction) }\end{array}$} & \multicolumn{2}{|c|}{$\begin{array}{c}\text { Model-3 } \\
\text { (DV: Turnover } \\
\text { Intention) } \\
\end{array}$} \\
\hline & $\beta$ & $\mathrm{t}$ & $\beta$ & $\mathrm{t}$ & $\beta$ & $\mathrm{t}$ \\
\hline Gender Discrimination &, $3164 * *$ & 4,3435 &,$- 2498 * *$ & $-3,7595$ &, $2368 * *$ & 3,3003 \\
\hline Career Satisfaction & & & & &,$- 3186 * *$ & $-4,8307$ \\
\hline $\mathrm{R}^{2}$ & \multicolumn{2}{|c|}{, 0691} & \multicolumn{2}{|c|}{, 0527} & \multicolumn{2}{|c|}{,1477 } \\
\hline $\mathrm{F}$ & \multicolumn{2}{|c|}{18,8661} & \multicolumn{2}{|c|}{14,1340} & \multicolumn{2}{|l|}{21,9306} \\
\hline
\end{tabular}

Moreover, both indirect effect $(.0328, .1523)$ and direct effect $(.0955, .3781)$ of $\mathrm{X}$ on $\mathrm{Y}$ are significant as seen in Table 4. Career satisfaction partially mediates the relationship between gender discrimination and turnover intention. Hence, $\mathbf{H}_{\mathbf{4}}$ is partially supported. 
Table 4. Mediating Effect of Career Satisfaction

\begin{tabular}{cccccc}
\hline & Effect & SE & $\mathrm{t}$ & $\mathrm{p}$ & $95 \%$ CI \\
\hline Indirect Effect & .0796 & .0302 & & & $(.0328, .1523)$ \\
Direct Effect & .2368 & .0717 & 3,3003 & .0011 & $(.0955, .3781)$ \\
Total Effect & .3164 & .0728 & 4,3435 & .0000 & $(.0717, .4598)$ \\
\hline
\end{tabular}

\section{Conclusion and Discussion}

The aim of this cross-sectional study was to investigate the relationship between perceived gender discrimination and turnover intention and explore the mediating effect of career satisfaction in the relationship between perceived gender discrimination and turnover intention.

$\mathrm{H}_{1}$ hypothesis 'Perceived gender discrimination is negatively related to career satisfaction' was supported. The findings on the relationship between gender discrimination and career satisfaction is consistent with the literature (e.g., Carr et al., 2000; Ecklund et al., 2012; Kern et al., 2020; Park et al., 2017). Employees who perceive gender discrimination, tend to be dissatisfied with their careers. $\mathrm{H}_{2}$ hypothesis 'Career satisfaction is negatively related to turnover intention' was supported. The result is consistent with the findings of the previous studies (e.g., Chan \& Mai, 2015; Chan et al., 2016; Joo \& Park, 2010; Salleh et al., 2020; Zopiatis et al., 2018). When female employees face career obstacles because of their gender, they tend to quit their current job and seek a new organization in which they fulfil their career goals. $\mathrm{H}_{3}$ hypothesis 'Perceived gender discrimination is positively related to turnover intention' was supported. The findings find support from the earlier studies (e.g., Foley et al., 2005; Foley et al., 2006; Qu et al., 2020; Shaffer et al., 2000). The positive relationship between perceived gender discrimination and turnover intention shows that when female employees feel restrained in an unjust and male dominant work environment, they tend to leave the current job and searching for other opportunities in different organizations. Finally, $\mathrm{H}_{4}$ hypothesis 'Career satisfaction will mediate the relationship between perceived gender discrimination and turnover intention' was partially supported. The results of the study showed that the mediating effect of career satisfaction between gender discrimination and turnover intention is partial. Gender discrimination may not entirely have an impact on turnover intention through career satisfaction.

The current research has two contributions to the literature. First, many scholars have researched considerably the relationship among perceived gender discrimination, career satisfaction and turnover intention and these studies generally investigated the direct effects (e.g., Shaffer et al., 2000). However, to our knowledge, the mediating role of career satisfaction in the relationship between gender discrimination and turnover intention was examined for the first time. The mediating effect indicates that when organizations can't provide equity among both female and male employees, female employees perceive gender discrimination. At this point they start to see their job requires unfair challenges and no chance in advancement in their career and therefore the female employees may be inclined to leave the job. The second contribution of this study to the existing global literature is including a sample of female employees in Turkey. The result of the study indicates that when Turkish female employees working in different sectors perceive discrimination in their workplace, they tend to leave the job. In addition, they are sensitive to career issues. 
For future research, the current study investigated the effect of gender discrimination on turnover intention with mediating effect of career satisfaction and found this effect was partial. Further studies may go beyond single mediator to describe the mechanism of impact of gender discrimination on employees' turnover intention. In other words, there could be other possible mediator variables in addition to career satisfaction, which may contribute to a better explanation of turnover intention in the context of gender discrimination. In addition, future studies may focus on different organizational level variables such as organizational climate, organizational trust, leader-member exchange, organizational politics, or other individual level variables such as role ambiguity and conflict, self-esteem, self-efficacy, worker productivity and personality types. The main limitations of this study are its cross-sectional nature and small sample size which is not adequate to represent the whole sample of the sectors.

For practical implications, turnover intention represents not just the employees' intention to leave the organization, but also it represents the loss of organization's qualified and talented employees. Gender discrimination is one of the stronger predictors of valuable employees' turnover intention. Female employees prevented from their career achievements by the lack of managerial support or unjust behaviour of their male counterparts, experience career dissatisfaction. In turn, career unsatisfaction determines the employees' intention to leave the job or organization. Therefore, promoting equal opportunities for female employees and reducing gender discrimination in the workplace should be an organizational goal. When a "just" workplace climate is created, employees perceive that diversity is valued and discrimination is discouraged. In addition, supporting female employees with the right attitude will lead to career satisfaction and improve their commitment to the organization. Not only women, but also men, prefer to work in a "friendly" work environment and such an environment supports successful employees to fulfil their career goals and encourages them to stay longer in the present organization. In the end, everyone wins.

\section{References}

Andersson, M. A., \& Harnois, C. E. (2020). Higher exposure, lower vulnerability? The curious case of education, gender discrimination, and Women's health. Social Science \& Medicine, 246, 112780. https://doi.org/10.1016/j.socscimed.2019.112780

Balkan, B., \& Cilasun, S. M. (2018, June). Does gender discrimination contribute to low labor force participation of women in turkey? Evidence from survey and field data. In Economic Research Forum Working Papers (No. 1205).

Baron, R. M., \& Kenny, D. A. (1986). The Moderator-Mediator Variable Distinction in Social Psychological Research: Conceptual, Strategic, and Statistical Considerations. Journal of Personality and Social Psychology, 51(6), 1173-1182. https://doi.org/10.1037/00223514.51.6.1173

Bhatt, W. (2013). The little brown woman: Gender discrimination in American medicine. Gender \& Society, 27(5), 659-680. https://doi.org/10.1177/0891243213491140

Bird, S. R., \& Rhoton, L. A. (2021). Seeing Isn’t Always Believing: Gender, Academic STEM, and Women Scientists' Perceptions of Career Opportunities. Gender \& Society, 35(3), 422-448. https://doi.org/10.1177/08912432211008814

Carr, P. L., Ash, A. S., Friedman, R. H., Szalacha, L., Barnett, R. C., Palepu, A., \& Moskowitz, M. M. (2000). Faculty perceptions of gender discrimination and sexual harassment in academic medicine. Annals of internal medicine, 132(11), 889-896. https://doi.org/10.7326/0003-4819-13211-200006060-00007 
Chan, S. H. J., \& Mai, X. (2015). The relation of career adaptability to satisfaction and turnover intentions. Journal of Vocational Behavior, 89, 130-139. https://doi.org/10.1016/j.jvb.2015.05.005

Chan, S. H., Mai, X., Kuok, O. M., \& Kong, S. H. (2016). The influence of satisfaction and promotability on the relation between career adaptability and turnover intentions. Journal of Vocational Behavior, 92, 167-175. https://doi.org/10.1016/j.jvb.2015.12.003

Chovwen, C. (2007). Barriers to acceptance, satisfaction, and career growth: Implications for career development and retention of women in selected male occupations in Nigeria. Women in Management Review, 22(1), 68-78. https://doi.org/10.1108/09649420710726238

Cohen, G., Blake, R. S., \& Goodman, D. (2016). Does turnover intention matter? Evaluating the usefulness of turnover intention rate as a predictor of actual turnover rate. Review of Public Personnel Administration, 36(3), 240-263. https://doi.org/10.1177/0734371X15581850

Crosby, F. (1976). A model of egoistical relative deprivation. Psychological review, 83(2), 85. https://doi.org/10.1037/0033-295X.83.2.85

Dilrukshi, U., \& Ranasinghe, V. (2021). Effect Of Gender Discrimination on Employee Performance: Mediating Role of Occupational Stress in Banking Sector Employees in Sri Lanka. Journal of Global Economics, Management and Business Research, 1-10.

Ding, C. G., \& Lin, C. P. (2006). Comparing the effects of determinants of turnover intentions between Taiwanese and US hospital employees. Human Resource Development Quarterly, 17(4), 403-421. https://doi.org/10.1002/hrdq.1183

Ecklund, E. H., Lincoln, A. E., \& Tansey, C. (2012). Gender segregation in elite academic science. Gender \& Society, 26(5), 693-717. https://doi.org/10.1177/0891243212451904

Elçi, M., Şener, İ., Aksoy, S., \& Alpkan, L. (2012). The impact of ethical leadership and leadership effectiveness on employees' turnover intention: The mediating role of work-related stress, 8th International Strategic Management Conference, Procedia - Social and Behavioral Sciences, 58, 289-297. https://doi.org/10.1016/j.sbspro.2012.09.1003

Foley, S., Hang-Yue, N., \& Wong, A. (2005). Perceptions of discrimination and justice: are there gender differences in outcomes? Group \& Organization Management, 30(4), 421-450. https://doi.org/10.1177/1059601104265054

Foley, S., Ngo, H. Y., \& Loi, R. (2006). Antecedents and consequences of perceived personal gender discrimination: A study of solicitors in Hong Kong. Sex Roles, 55(3), 197-208. https://doi.org/10.1007/s11199-006-9073-4

Gerçek, M., Atay, S. E., \& Dündar, G. (2015). The Effect of Work-Life Balance and Career Satisfaction on Intention to Leave. The Journal of KAU IIBF, 6(11), 67-86.

Greenhaus, J. H., Parasuraman, S., \& Wormley, W. M. (1990). Effects of race on organizational experiences, job performance evaluations, and career outcomes. Academy of Management Journal, 33(1), 64-86. https://doi.org/10.5465/256352

Griffeth, R. W., Hom, P. W., \& Gaertner, S. (2000). A Meta-Analysis of Antecedents and Correlates of Employee Turnover: Update, Moderator Tests and Research Implications for the Next Millennium. Journal of Management, 26, 463-488. https://doi.org/10.1177/014920630002600305

Hayes, A. F. (2013). Introduction to mediation, moderation, and conditional process analysis: $A$ regression-based approach. Guilford Press.

Herrbach, O., \& Mignonac, K. (2012). Perceived gender discrimination and women's subjective career success: The moderating role of career anchors. Relations Industrielles/Industrial Relations, 67(1), 25-50. https://doi.org/10.7202/1008194ar

Homans, G. (1961). Social behavior: its elementary forms. Harcourt Brace Jovanovich.

Jagusztyn, N. E. (2010). Perceived Workplace Discrimination as a Mediator of the Relationship between Work Environment and Employee Outcomes: Does Minority Status Matter?

Janjua, M. B., Inam, H., Martins, R. S., Zahid, N., Sattar, A. K., Khan, S. M., Darbar, A., Faruqui, N., Akram, S., Enam, S. A., Haider, A. H., \& Malik, M. A. (2020). Gender discrimination against female surgeons: A cross-sectional study in a lower-middle-income country. Annals of Medicine and Surgery, 57, 157-162. https://doi.org/10.1016/j.amsu.2020.07.033 
Joo, B. K. B., \& Park, S. (2010). Career satisfaction, organizational commitment, and turnover intention. Leadership \& Organization Development Journal, 31(6), 482-500. https://doi.org/10.1108/01437731011069999

Kang, H. J., Gatling, A., \& Kim, J. (2015). The impact of supervisory support on organizational commitment, career satisfaction, and turnover intention for hospitality frontline employees. Journal of Human Resources in Hospitality \& Tourism,14(1), 68-89. https://doi.org/10.1080/15332845.2014.904176

Kern, C. C., Kenefic, L. S., Dockry, M. J., \& Cobo-Lewis, A. (2020). Discrimination and career satisfaction: Perceptions from US Forest Service scientists. Journal of Forestry, 118(1), 44-58. https://doi.org/10.1093/jofore/fvz057

Kezar, A., \& Acuña, A. L. (2021). Gender Inequality and the New Faculty Majority. The Wiley Handbook of Gender Equity in Higher Education, 105-124. https://doi.org/10.1002/9781119257639.ch6

Kim, H. K., Lee, U. H., \& Kim, Y. H. (2015). The effect of workplace diversity management in a highly male-dominated culture. Career Development International, 20(3), 259-272. https://doi.org/10.1108/CDI-06-2014-0082

Kim, S. (2015). The effect of gender discrimination in organization. International Review of Public Administration, 20(1), 51-69. https://doi.org/10.1080/12294659.2014.983216

Lee, J., Rehner, T., \& Forster, M. (2010). Employees' intentions to remain employed in child welfare: Testing a conceptual model. Journal of Public Child Welfare, 4(2), 174-197. https://doi.org/10.1080/15548731003799613

Lepnurm, R., Dobson, R., Backman, A., \& Keegan, D. (2006). Factors explaining career satisfaction among psychiatrists and surgeons in Canada. The Canadian Journal of Psychiatry, 51(4), 243-255. https://doi.org/10.1177/070674370605100406

Lourens, A. (2014). The development of co-curricular interventions to strengthen female engineering students' sense of self-efficacy and to improve the retention of women in traditionally maledominated disciplines and careers. South African Journal of Industrial Engineering, 25(3), 112125. https://doi.org/10.7166/25-3-502

Lv, Y., \& Yu, X. (2020). Effect of employee career satisfaction on organizational citizenship behavior. Social Behavior and Personality: An international journal, 48(10). https://doi.org/10.2224/sbp.9126

Martínez-León, I. M., Olmedo-Cifuentes, I., \& Ramón-Llorens, M. C. (2018). Work, personal and cultural factors in engineers' management of their career satisfaction. Journal of Engineering and Technology Management, 47, 22-36. https://doi.org/10.1016/j.jengtecman.2017.12.002

Mobley, W. H., Griffeth, R. W., Hand, H. H., \& Meglino, B. M. (1979). Review and conceptual analysis of the employee turnover process. Psychological Bulletin, 86(3), 493-522. https://doi.org/10.1037/0033-2909.86.3.493

Nunnaly, J. C. (1978). Psychoneric Theory (2 ${ }^{\text {nd }}$ ed.). McGraw-Hil.

Özkan, A. H., Elci, M., Karabay, M. E., Kitapci, H., \& Garip, C. (2020). Antecedents of turnover intention: A meta-analysis study in the United States. E+M Ekonomie a Management, 23(1), 93110. https://doi.org/10.15240/tul/001/2020-1-007

Park, S. G., Kang, H. J., Lee, H. R., \& Kim, S. J. (2017). The effects of LMX on gender discrimination and subjective career success. Asia Pacific Journal of Human Resources, 55(1), 127-148. https://doi.org/10.1111/1744-7941.12098

Pelenk, S. E. (2020). Lider-Üye Etkileşiminin Kariyer Memnuniyetine Etkisinde Algılanan Güç Mesafesinin Aracilık Rolü [The Mediator Role of Perceived Power Distance in the Effect of Leader-Member Exchange on The Career Satisfaction]. Yönetim ve Ekonomi Araştırmalarl Dergisi/Journal of Management and Economics Research, 18(3), 25-45. https://doi.org/10.11611/yead.756545

Qu, Y., Jo, W., \& Choi, H. C. (2020). Gender discrimination, injustice, and deviant behavior among hotel employees: role of organizational attachment. Journal of Quality Assurance in Hospitality \& Tourism, 21(1), 78-104. https://doi.org/10.1080/1528008X.2019.1619498 
Ren, H., Bolino, M. C., Shaffer, M. A., \& Kraimer, M. L. (2013). The influence of job demands and resources on repatriate career satisfaction: A relative deprivation perspective. Journal of World Business, 48(1), 149-159. https://doi.org/10.1016/j.jwb.2012.06.015

Salleh, A. M. M., Omar, K., Aburumman, O. J., Mat, N. H. N., \& Almhairat, M. A. (2020). The impact of career planning and career satisfaction on employee's turnover intention. Entrepreneurship and Sustainability Issues, 8(1), 218. https://doi.org/10.9770/jesi.2020.8.1(14)

Seibert, S. E., \& Kraimer, M. L. (2001). The Five-Factor Model of Personality and Career Success. Journal of Vocational Behavior, 58(1), 1-21. https://doi.org/10.1006/jvbe.2000.1757

Shaffer, M. A., Joplin, J. R. W., Bell, M. P., Lau, T., \& Oguz, C. (2000). Gender discrimination and jobrelated outcomes: A cross-cultural comparison of working women in the United States and China. Journal of Vocational Behavior, 57(3), 395-427. https://doi.org/10.1006/jvbe.1999.1748

Sheridan, A., \& Newsome, L. (2021). Tempered disruption: Gender and agricultural professional services. Gender, Work \& Organization, 28, 1040-1058. https://doi.org/10.1111/gwao.12623

Siong, Z. M. B., Mellor, D., Moore, K. A., \& Firth, L. (2006). Predicting Intention to Quit in the Call Centre Industry: Does the Retail Model fit? Journal of Managerial Psychology, 21(3), 231-243. https://doi.org/10.1108/02683940610659579

Tett, R. P., \& Meyer, J. P. (1993). Job satisfaction, organizational commitment, turnover intention, and turnover: Path analyses based on meta-analytic findings. Personnel Psychology, 46, 259-293. https://doi.org/10.1111/j.1744-6570.1993.tb00874.x

Traavik, L. E. (2018). Career equality: Inclusion and opportunities in a professional service firm in Norway. Gender in Management: An International Journal, 33(6), 451-465. https://doi.org/10.1108/GM-07-2017-0092

Treanor, L., Marlow, S., \& Swail, J. (2021). Rationalizing the postfeminist paradox: The case of UK women veterinary professionals. Gender, Work \& Organization, 28(1), 337-360. https://doi.org/10.1111/gwao.12568

Yücelen, M., \& Özen, A. K. (2010). Aile Sirketlerinde Kadın Yöneticiler: Basarılı ve Basarısız Kadının Düsmanı Kim? [Women Executives in Family Businesses: Who Are the Enemies of Successful and Unsuccessful Women?]. Entre 2010 International Conference on Entrepreneurship, Family Business and Innovation, 325-336.

Zopiatis, A., Theocharous, A. L., \& Constanti, P. (2018). Career satisfaction and future intentions in the hospitality industry: An intrinsic or an extrinsic proposition? Journal of Human Resources in Hospitality \& Tourism, 17(1), 98-120. https://doi.org/10.1080/15332845.2017.1340748 